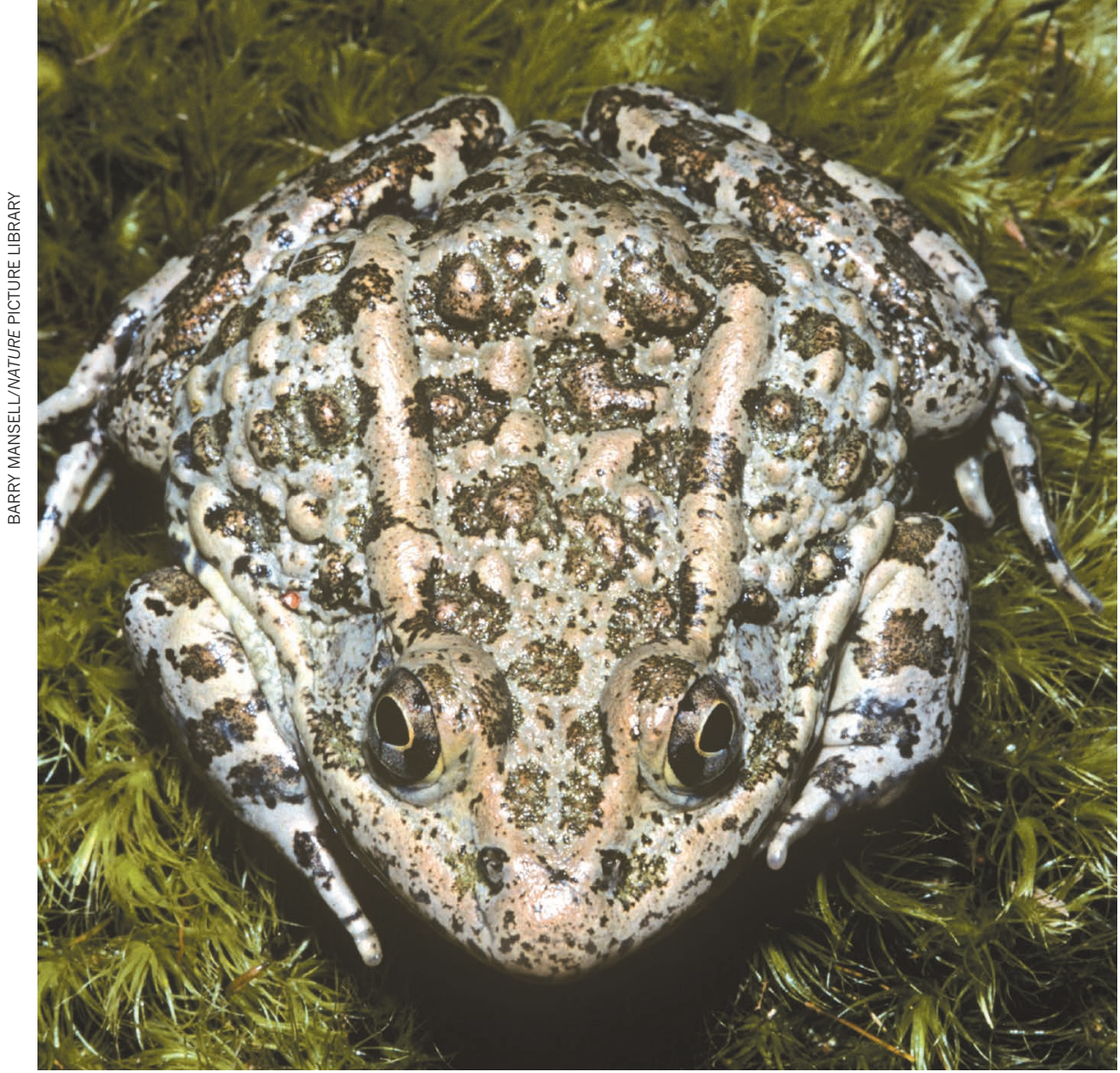

The dusky gopher frog is at the centre of a pitched legal battle over the Endangered Species Act.

LAW

\title{
Science and the Supreme Court
}

\section{The research-related cases awaiting the top USjudges.}

\section{BY SARA REARDON}

$\mathrm{T}$ he ideological balance of the US Supreme Court shifted to the right on 6 October, as the Senate voted to confirm federal judge Brett Kavanaugh for a seat on the nation's highest court.

Kavanaugh becomes the fifth conservative justice on the nine-member court, which began its latest term on 1 October. Nature looks at the science-related cases that are on the court's docket, and others that are likely to advance in the near future.

\section{ENDANGERED SPECIES}

The Supreme Court's first case of the term centres on the dusky gopher frog (Lithobates sevosus). Development projects have destroyed the amphibian's natural habitat in the southeastern United States, and fewer than 100 of the frogs remain, in a trio of ponds in Mississippi.

To save the species, the US Fish and Wildlife Service (FWS) wants to restore ponds on 2,621 hectares of land in Louisiana owned by timber companies, and then move the animals there. "If you don't do that, the frog is doomed," says Patrick Parenteau, an environmental lawyer at the Vermont Law School in South Royalton.

But the timber companies argue that the pond plan oversteps the bounds of the Endangered Species Act (ESA) of 1973. The law requires the government to protect endangered species' habitats, but does not specify whether this applies to land not currently suitable for a species to occupy.

The case, which justices heard on 1 October, is only the fifth challenge to the ESA to come before the Supreme Court. A ruling in favour of the FWS could pave the way for the government to seize private land and create habitat for other endangered animals and plants - at a time when climate change is rendering many species' longtime habitats unsuitable.

\section{DEATH PENALTY}

People whose mental disabilities prevent them from understanding their crime or guilt cannot legally be put to death in the United States. The Supreme Court is poised to decide whether this ban applies to people who were mentally capable when they committed a crime but later developed cognitive impairments.

On 2 October, the court heard arguments in the case of Vernon Madison, who was sentenced to death for murdering an Alabama police officer in 1985. Madison suffered several strokes on death row and is now unable to remember committing the crime. His lawyers say that executing Madison would constitute cruel and unusual punishment.

The state of Alabama argues that Madison can understand its reasoning for putting him to death if the situation is explained to him. But experts say that this understanding is limited. "Madison can mouth the words, but it really comes down to a value judgement: if this person displays these symptoms, is that someone who can prepare themselves for death?" asks Daniel Volchok, an attorney at the firm WilmerHale in Washington DC.

The American Psychological Association and the American Psychiatric Association filed a joint brief in support of Madison. They say that brain imaging and cognitive tests prove that Madison, who is unable to walk or care for himself, cannot truly comprehend the rationale behind his punishment.

\section{CLIMATE CHANGE}

The Supreme Court has not yet agreed to hear any cases this term involving climate change. But the Trump administration has worked to roll back a wide range of climate regulations, prompting a wave of lawsuits. Some of those will reach the Supreme Court, says Sharon Jacobs, an environmental lawyer at the University of Colorado Boulder.

Potential cases this term include a challenge to the Federal Energy Regulatory Commission's decision to limit consideration of climate change when it evaluates applications for new natural-gas pipelines. Earlier this year, the agency said it would no longer require companies to address the climate impact of burning the gas in their licence applications.

Another suit that could end up on the docket seeks to limit the reach of the Clean Air Act. The law, which took effect in 1990, banned chemicals called chlorofluorocarbons (CFCs) that destroy the ozone layer. Some manufacturers then switched to using hydrofluorocarbons (HFCs), which do not deplete ozone but are powerful greenhouse gases.

In 2015, the US Environmental Protection Agency (EPA) ordered two companies, Mexichem Fluor and Arkema, to switch to lessharmful chemicals - and the firms fought back, arguing that the Clean Air Act applies only to CFCs. Last year, Kavanaugh wrote a lower-court ruling that said the EPA could not require companies that were using HFCs to replace them with less-damaging chemicals. Environmental groups and companies that make replacements for HFCs appealed on the agency's behalf.

If the case reaches the Supreme Court, Kavanaugh will probably recuse himself increasing the likelihood of a split decision. - 